HID 46 (2019)

\title{
LA FLOTA CASTELLANA DURANTE LA GUERRA CONTRA LA CORONA DE ARAGÓN DE 1429-30: ARMAMENTO DE BUQUES, TRIPULACIONES, ORDENANZAS NAVALES Y CAMPAÑA BÉLICA
}

\author{
THE CASTILIAN FLEET DURING THE WAR AGAINST THE \\ CROWN OF ARAGON OF 1429-30: RIGGING OF SHIPS, CREWS, \\ NAVAL ORDINANCES AND WAR CAMPAIGN
}

\author{
José Marcos García IsAaC \& CARMEN IdÁÑEZ ViCENTE \\ Universidad Complutense de Madrid \\ josemarcosgarciaisaac@gmail.com ORCID: https://orcid.org/0000-0002-0039-8261 \\ carmenidanezvicente@gmail.com ORCID: https://orcid.org/0000-0003-1564-838X
}

RESUMEN: El objetivo principal del presente artículo, es dar a conocer el papel que jugó la flota castellana durante el conflicto armado que enfrentó a dicho reino contra la Corona de Aragón, entre 1429-30. Esta contienda, aunque ya ha sido bastante estudiada, el papel que desempeñó en el mismo la escuadra de Castilla no se conoce en profundidad, principalmente, por el desconocimiento general de los fondos municipales de Orihuela y Elche, donde se encuentran el mayor número de referencias a este respecto. Por lo tanto, gracias a la documentación conservada en estos archivos del territorio perteneciente al antiguo Reino de Valencia, pretendemos presentar una visión histórica totalmente renovada sobre el papel de la marina de guerra castellana en esta contienda.

PalabRAS ClaVe: Castilla; Aragón; flota; puertos; almirante de Castilla.

ABSTRACT: The aim of this paper is to show the role played by the Castilian navy during the armed conflict that faced the kingdom against the Crown of Aragon, between 1429-30. Although the struggle has been well studied, the role played by the fleet of Castile is not known in depth, mainly due to the fact that the general ignorance of the municipal funds of Orihuela and Elche, where the largest number of references in this regard. Therefore, thanks to the documentation kept in these archives of the territory of the ancient Kingdom of Valencia, we intend to present a totally renewed historical vision on the role of the Castilian navy in that war.

Keywords: Castile; Aragon; fleet; ports; Admiral of Castile.

Recibido: 28-12-2018; Aceptado: 12-3-2019; Versión definitiva: 12-3-2019.

Copyright: (C) Editorial Universidad de Sevilla. Este es un artículo de acceso abierto distribuido bajo los términos de la licencia de uso y distribución Creative Commons Reconocimiento-No-ComercialSinObraDerivada 4.0 (CC BY-NC-ND 4.0) 


\section{INTRODUCCIÓN}

Desde 1425, la tensión entre las coronas de Castilla y Aragón era cada vez mayor. En efecto, la presión de los infantes aragoneses Juan y Enrique, hermanos de Alfonso V de Aragón, por controlar la vida política castellana, estaba empeorando las relaciones personales entre el soberano castellano, Juan II de Castilla, con su primo aragonés, principalmente, tras la encarcelación del infante Enrique, quien, ostentaba desde los nueve años el cargo de maestre de Santiago. En ese año, tras la firma del conocido como "pacto de Araciel", los embajadores aragoneses consiguieron la liberación del infante Enrique, a cambio de que éste jurase una total fidelidad a su primo castellano ${ }^{1}$. Aunque la concordia entre las dos ramas de la casa de Trastámara parecía haberse restablecido, no obstante, Juan II de Castilla, o al menos sus consejeros, debieron creer que en un futuro conflicto entre Castilla y Aragón podía ser posible y, para ello, Castilla debía contar no solo con un potente ejército terrestre, sino también con una armada fuerte para repeler la amenaza naval aragonesa.

La mejora de la flota castellana era un tema que llevaba algunos años intentándose abordar en la vida política de la Corona de Castilla. Sobre este asunto, ya en las cortes de 1422 los procuradores aconsejaron a Juan II de lo conveniente que sería para el reino que el monarca mandase fazer armada ${ }^{2}$. Estos planes para la mejora del poder naval castellano comenzaron a finales del año $1427 \mathrm{y}$, consistieron en la construcción de un nuevo arsenal de galeras que complementara al ya existente, es decir, a las atarazanas de Sevilla. El lugar elegido fue la villa de Santander ${ }^{3}$, donde se sabe de la existencia de unas atarazanas que, posiblemente, debieron quemarse durante el incendio que arrasó la villa en $1425^{4}$.

El responsable de la construcción de las nuevas instalaciones, quien, además, recibió el nombramiento de alcaide de las mismas, fue Juan de Silva, notario mayor del Reino de Toledo 5 . El lugar seleccionado para la construcción de las nuevas

1. Sáiz Serrano 2008, p. 26.

2. VV. AA. 1866, pp. 39-40. Véase también: Fernández Duro 2010, p. 188.

3. Archivo Histórico de la Nobleza (en adelante AHNob), Cifuentes, Cp. 417, doc. 10; apéndice documental $\mathrm{n}^{\circ}$ I. Este albalá de Juan II, completamente inédito hasta la fecha, es posiblemente el documento más importante conservado sobre las atarazanas reales de Santander. Para una visión más general de las atarazanas santanderinas, véase: Casado Soto 1983-1986, pp. 59-84. Santander, además, se encontraba próxima a ciertas comarcas con una larga tradición de explotación maderera para la construcción de flotas reales. Tal era el caso de la provincia de Guipúzcoa, en donde ya a finales del reinado del rey Alfonso XI, en un documento expedido durante el cerco de Gibraltar, se menciona como "la madera de los robres era muy menesterosa para faser las naos, e las galeas e los otros navíos que conplían para nuestro serviçio..." Archivo de la Real Chancillería de Valladolid, Real Audiencia y Chancillería de Valladolid, Pergaminos, Cp. 38, doc. 7.

4. La mención de estas primeras atarazanas se encuentra en un documento de 1396. Véase: Solórzano Telechea 2002, pp. 93-94 y García de Castro 2014, pp. 121-122. El origen de las mismas, probablemente, se encuentre en la decisión adoptada por Enrique II en 1372 de convertir a la villa de Santander, de facto, en la principal base de galeras castellanas del Cantábrico. Véase: García Isaac, Idáñez Vicente 2018, p. 80.

5. Sobre este personaje, véase: Cañas Gálvez 2012, p. 65. Según Salazar y Castro 1686, p. 247, en 1435 cobraba del rey por el cargo de regidor de Toledo y alcaide de las atarazanas un total de 5.000 maravedís. 
atarazanas, al parecer, fue el solar de las anteriores, pues se indica en el albalá que remitió Juan II que en dicho lugar se encontraban las quatro galeas que Gonçalo Gonçáles de Setién ${ }^{6}$, por mi mandado, puso dentro de la dicha villa ${ }^{7}$. El control económico de las obras estuvo administrado por Ferrán Sánchez de Hurones, escribano y contador de Juan II $^{8}$.

Un mes después, el 24 de enero de 1428, Juan II pidió a las ciudades castellanas que colaborasen con las obras de las atarazanas de Santander y para la fabricación de materiales para las galeras. Aunque solo se ha conservado una carta a este respecto en el Archivo Municipal de Murcia, probablemente, más villas y ciudades debieron de colaborar en este asunto ${ }^{9}$. Aparte de esta medida, en las semanas y meses siguientes, el soberano castellano mandó a diversos personajes grandes cantidades de maravedís, para la construcción de navíos ${ }^{10}$. En esa misma documentación, se menciona la entrega de 1.017.283 maravedís a Juan de Silva, pues, dicha cantidad fue la que tomó de Juan II para la construcción de las atarazanas de Santander, además de las cinco galeras que le ordenó construir en dichas instalaciones ${ }^{11}$. Por último, Juan de Escalante, responsable de los almacenes de las atarazanas, recibió 253.100 maravedís, quel rey le mandó prestar por un su alvalá, por cierto fierro, e madera e otras cosas que vendió ${ }^{12}$.

En cuanto a las atarazanas de Sevilla ${ }^{13}$, se sabe que en 1428 también estaban construyéndose y arreglándose en ese arsenal cierta cantidad de galeras. Así lo atestiguan las actas capitulares de Jerez de la Frontera. En efecto, el 12 de marzo de aquel año, se leyó en el cabildo de dicha población una carta de Diego Fernández de Vadillo, veinticuatro de Sevilla y alcalde de las atarazanas sevillanas, en la cual, pidió a las autoridades jerezanas que enviasen a sus carreteros con cierta cantidad de madera, la cual, era menester para las galeas que nuestro señor el rey

6. Además de ocupar la lugartenencia de las atarazanas reales de Santander en nombre de Juan de Silva, también ostentaba dicha dignidad subalterna para la notaria mayor de Toledo: Cañas Gálvez 2012, p. 245.

7. AHNob, Cifuentes, Cp. 417, doc. 10; apéndice documental n ${ }^{\circ} \mathrm{I}$.

8. Pese a las medidas de Juan II para intentar convertir a las atarazanas reales de Santander en un potente centro de construcción naval, la vida de estas instalaciones fue bastante efímera, pues, en un documento de 1504, ya se indicaba que se encontraba en un estado ruinoso. A este respecto, véase: Casado Soto 1985, p. 654 y Solórzano Telechea 1995, p. 428.

9. Archivo Municipal de Murcia (en adelante AMM), leg. 4271, $\mathrm{n}^{\circ} 13$. El documento se encuentra publicado en: Abellán Pérez 1984, pp. 360-361.

10. Archivo General de Simancas (en adelante AGS), Escribanía Mayor de Rentas, leg. 1, f. 94r. Una descripción de todos los personajes a los que el rey ordenó la construcción de embarcaciones, junto con las cantidades que recibieron, puede verse en: Álvarez Palenzuela 2017, pp. 64-65. Entre estos nombres, sin duda alguna, el más destacado es el de Pero Niño, señor de Cigales, quien, recibió de Juan II un total de 80.000 maravedís para la construcción de un navío. Este dato, por lo tanto, indica que Pero Niño nunca abandonó del todo el mundo y ambiente marítimo, aunque hacía muchos años que no participaba en ninguna campaña naval. También destaca el nombre de Ferrán Sánchez de Hurones, personaje que ya mencionamos anteriormente, quien, recibió del monarca un total de 72.000 maravedís.

11. AGS, Escribanía Mayor de Rentas, leg. 1, f. 94v

12. AGS, Escribanía Mayor de Rentas, leg. 1, f. 95 r.

13. Para una visión general de estas instalaciones durante la Baja Edad Media, véase: Fernández Rojas 2013, pp. 39-50. 
agora manda fazer e adobar ${ }^{14}$. Unos meses antes, Juan II había escrito al concejo de Sevilla y a Diego Fernández de Vadillo, estableciendo el número óptimo de empleados que debían servir en las atarazanas ${ }^{15}$.

Como demuestran todos estos datos, Juan II estaba organizando una ambiciosa política de rearme naval, con la intención de reforzar el ya existente poder naval castellano. En efecto, era conveniente contar una flota potente ante una eventual guerra contra la Corona de Aragón, la cual, se veía cada vez más cercana. ¿Se puede precisar con seguridad si la flota castellana, antes de las medidas adoptadas por Juan II, se encontraba en un estado óptimo? Es difícil, aunque es probable que no se encontrase en condiciones de igualdad, o al menos de total superioridad, respecto a la flota aragonesa, su principal oponente en esos años ${ }^{16}$. Independientemente de la situación naval de cada una de las coronas, al final, la tensión entre los dos reinos fue incontrolable, lo que conllevó el inicio de las hostilidades en el verano de $1429^{17}$.

\section{Armamento DE LA FLOTA}

Tras el estallido del conflicto, Juan II tardó en dar las instrucciones pertinentes para comenzar a armar la flota de guerra castellana. ¿A qué se debió esta demora? En nuestra opinión, lo más probable es que el monarca castellano no creyese, cuando comenzaron las hostilidades, que la contienda se desarrollara de una manera tan intensa. La primera disposición, a este respecto, se fecha el 7 de diciembre de 1429, cuando ordenó al almirante de Castilla, Fadrique Enríquez ${ }^{18}$, que comenzase los preparativos para el armamento de la flota. Además, le indicó que solo debería combatir, exclusivamente, contra naves de súbditos del rey de Aragón ${ }^{19}$.

No obstante, según José Manuel Calderón Ortega, la fecha de ese documento, al igual que el resto de cartas enviadas por Juan II a distintos personajes sobre

14. Archivo Municipal de Jerez de la Frontera (en adelante AMJF), Acta Capitular de 1428, f. 15v; Orellana González 2015, p. 136.

15. Bello León; Martín Perera 2012, pp. 89-81. Véase también: Fernández Rojas 2013, p. 46 y Pérez-Mallaína 2015, pp. 220-221.

16. Algunos años atrás, en 1420, Alfonso V de Aragón había organizado una poderosa armada para combatir a los rebeldes sardos. Por lo tanto, en nuestra opinión no es descabellado pensar que Aragón contara con un mayor poder naval, al menos en cuanto al número de galeras se refiere, en comparación a Castilla. No obstante, muchas de las galeras armadas para dicha expedición ya habrían sido desarmadas y estarían inoperativas. Sobre la preparación de dicha flota, véase: Ryder 1992, pp. 98-99.

17. Para una visión general del conflicto castellano-aragonés de 1429/30, véase: Sáiz Serrano 2008, pp. 27-33.

18. Sobre este personaje, véase: Calderón Ortega 2003, pp. 77-123. Fadrique había relevado a su padre, Alonso Enríquez, del cargo de almirante de Castilla tres años atrás, tras la renuncia de éste último, por lo que su experiencia personal en contiendas navales debía ser limitada. El documento de Juan II confirmando su nombramiento, con fecha de 12 de junio de 1426, se encuentra en: Archivo Ducal de Alba (en adelante ADA), C. 77, n 17. Publicado en: Calderón Ortega 2003, pp. 343-346.

19. Fernández de Navarrete 1858, p. 531. 
este asunto, sería 9 de diciembre ${ }^{20}$. En nuestra opinión, esta afirmación es correcta. No obstante, en una carta enviada por Fadrique Enríquez a Martín López de Córdoba, pagador de la armada de la costa de la mar de Castilla, con fecha de 20 de septiembre de 1429, ya se hacía mención de las pagas para los patrones de las embarcaciones $^{21}$. Dos meses después, el 20 de noviembre, escribió a los capitanes de las naves, indicándoles que su cuñado, Juan de Tovar ${ }^{22}$, ostentaría el cargo de capitán mayor de la flota ${ }^{23}$. Según creemos, es bastante probable que Juan II pidiera al almirante, que comenzase los preparativos para la futura expedición naval antes de la propia aprobación real ${ }^{24}$. Se debe tener en cuenta y, así creemos que hubo de pensarlo el propio rey Juan II, que armar una flota era un proceso lento y costoso. Por lo tanto, incluso sin contar con el beneplácito de las Cortes o de los contadores mayores, era conveniente no demorar demasiado la puesta a punto de los bajeles y el reclutamiento de las tripulaciones, pues, el almirante y sus agentes eran los principales responsables en llevar a cabo estas tareas.

Retomando la cuestión de las misivas que envió el rey en diciembre de 1429 a los principales responsables, junto con el almirante, del buen hacer y desarrollo del armamento de la flota, éste se dirigió a los concejos marítimos ${ }^{25}$, a los súbditos y naturales de sus reinos que pudieran ir en la campaña con el almirante ${ }^{26}$, con la intención de anunciarles los preparativos de la flota. Además, volvió a escribir a los municipios de la costa, pidiéndoles que tratasen del mejor modo posible al almirante Fadrique, o a cualquier de sus oficiales que actuase en su nombre ${ }^{27}$.

En términos similares, también remitió las correspondientes letras a Martín López de Córdoba, pagador de la armada del Cantábrico ${ }^{28}$, a los distintos oficiales de la administración castellana ${ }^{29}$, a Ruy Díaz, pagador de la flota de Sevilla ${ }^{30}$, a Alfonso Guillén de Caso, tenedor de los hornos del bizcocho de Sevilla ${ }^{31}$, a Juan

20. Calderón Ortega 2003, p. 84.

21. Fernández de Navarrete 1858, pp. 544-545.

22. Juan de Tovar era hijo del famoso almirante Fernán Sánchez de Tovar, quien, en el verano de 1381, derrotó en Saltés a una poderosa armada portuguesa. Su parentesco con el almirante Fadrique Enríquez se debía a su mujer, Constanza Enríquez, hermana de éste último. Curiosamente, en mayo de 1430, obtuvo licencia de Juan II para poder fundar un mayorazgo, en la figura de su hijo Luis, en sus señoríos de Berlanga, Astudillo y Gelves: AHNob, Frías, Caj. 312, doc. 1-6. Probablemente, la intención de Juan de Tovar de establecer este mayorazgo se debiese al temor de fallecer en la campaña naval que estaba próxima a realizarse contra la Corona de Aragón.

23. Ibid., pp. 545-546.

24. Según indica García de Santa María 1892, p. 128, durante las cortes que reunió el rey en Burgos al comienzo de la contienda, los contadores mayores ya trabajaban con la intención de conseguir una satisfactoria financiación de los efectivos militares castellanos, incluida la armada.

25. Fernández de Navarrete 1858, pp. 531.532.

26. Ibid., p. 532.

27. ADA, C. 77, nº 19; Fernández de Navarrete 1858, pp. 532-533,

28. Fernández de Navarrete 1858, pp. 533-534.

29. Ibid., pp. 534-535.

30. Ibid., pp. 536-537.

31. Ibid., pp. 537-538. 
de Silva y Gonzalo González de Setién ${ }^{32}$, a Diego Fernández de Vadillo ${ }^{33}$, a Ruy Gutiérrez de Escalante, armador de las naves de la costa de la mar de Castilla, a Juan de Pámanes, Fernán González Marín y Juan de Escalante ${ }^{34}$, a Pedro López de Sandoval, alcaide de los alcázares de Sevilla ${ }^{35}$. Por último, en enero de 1430, Juan II remitió tres cartas al almirante, en las cuales, otorgó un poder a Fadrique Enríquez para poder tratar en nombre del rey con cualquier concejo, prometer mercedes para todos aquellos que colaborasen con la flota y, además, el poder de perdonar los delitos de aquellos súbditos del monarca castellano que quisieran enrolarse en la armada ${ }^{36}$. El almirante también ejerció su jurisdicción, enviando diversas cartas, entre otros, a Juan de Silva, Gonzalo González de Setién, Martín López de Córdoba, los patrones de las naves y los concejos de la costa ${ }^{37}$.

Toda esta documentación publicada por Martín Fernández de Navarrete es excepcional, pues, permite localizar a los principales actores encargados de la preparación de la flota castellana ${ }^{38}$. No obstante, en cuanto a referencias sobre armamento de naves y tripulaciones se refiere, es bastante parca. La única información relevante, a este respecto, es una lista con los nombres de los capitanes de algunos de los balleneres y naos armadas en el Cantábrico ${ }^{39}$, la cual, junto con el resto de patrones que se mencionan en otros dos documentos ${ }^{40}$, además de la nómina de los que capitaneaban las galeras ${ }^{41}$, permiten conocer a la perfección quienes eran los marinos responsables del gobierno de las distintas naves que conformaban la flota.

Pero, ¿cuántas embarcaciones consiguió reunir el almirante? No está del todo claro, aunque si es posible establecer un número muy aproximado. Como mencionamos anteriormente, según el cronista Álvar García de Santa María, los contadores mayores creían que el número óptimo de embarcaciones de la flota debía ser 24 o 25 galeras, unas 30 naos y un número indeterminado de carracas y otras fustas de menor tamaño $0^{42}$. El mismo autor, menciona que finalmente fueron 14 las galeras que se armaron en las atarazanas de Sevilla, junto con otras dos carracas. En cuanto a las embarcaciones armadas en Santander, el manuscrito original del texto presenta en dicho pasaje una laguna ${ }^{43}$. En una carta enviada por el consell de Orihuela a las autoridades municipales de Eche y Alicante a finales de junio de 1430, tras conocer la llegada de la flota castellana al puerto de Cartagena, se

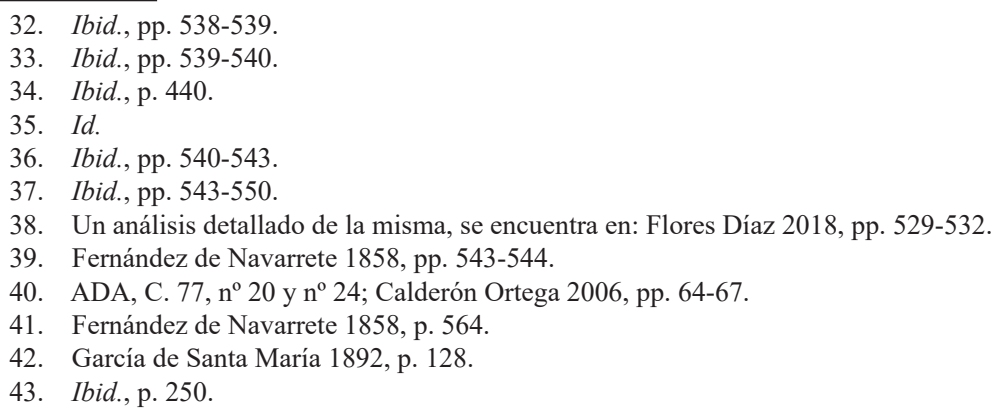


indicaba que eran un total de quaranta set fustes de remes e quaranta cinch naus, una cifra, desde luego, bastante exagerada ${ }^{44}$.

Gracias a la documentación conservada en la sección "Contaduría Mayor del Sueldo" del Archivo General de Simancas, se puede conocer de una forma bastante certera el número total de galeras que conformaban la flota. En efecto, según las cuentas presentadas por Juan Sánchez de Bilbao, criado y secretario del almirante ${ }^{45}$, se sabe que se armó en la muy noble çibdad de Sevilla XV galeas, e en Santander çinco, que eran veynte ${ }^{46}$. Esta misma cifra se ofrece en el texto del pleito homenaje que se tomó al almirante de Castilla cuando la flota estuvo lista ${ }^{47}$. En dicho documento, además, se indicó que fueron armadas 30 naos, una carraca y cinco balleneres ${ }^{48}$. Esta información también se recogió en las cuentas de Juan Sánchez de Bilbao, donde se especificó que en Santander se armaron el dicho año de $X X X$ (...) $X X X$ naos e çinco balleneres ${ }^{49}$. Por lo tanto, consideramos que las cifras de embarcaciones reflejadas en las cuentas del secretario de Fadrique Enríquez deben ser las más aproximadas a la realidad.

En cuando a la tripulación enrolada en la armada, destacamos que solo los galeotes, ballesteros y hombres de armas embarcados en las galeras pueden ser contabilizados con cierta exactitud ${ }^{50}$. Referente a los primeros, se sabe que se repartieron e fizieron en las behetrías de Castilla IIIMDC peones galeotes. E les dieron de sueldo, a cada uno, mill maravedis $s^{51}$. No se menciona a lo largo del documento si los galeotes de behetrías debían servir exclusivamente en las galeras armadas en Santander o también en las sevillanas y, además, tampoco se indica el número de galeotes por bajel. En unas cuentas bastante detalladas del número de tripulantes de una galera armada en Sevilla en 1380, se indicaba que el cómputo total de galeotes en la misma fue de 174 remeros $^{52}$. Así pues, si se acepta este dato como válido también para las galeras de la escuadra castellana de 1430, se comprueba que el número de galeotes reclutados en behetrías superaba el número total de los necesarios para las galeras de Santander. Por lo tanto, en principio, los 3.600 remeros reclutados debían ser suficientes para toda la flota. En cuanto a

44. Archivo Municipal de Elche (en adelante AME), a7, f. 37v. Véase también: Ponsoda López de Atalaya 2010, p. 702.

45. Dicho personaje, además, ostentaba el cargo de notario del rey, pues, fue el encargado de tomar juramento a Fadrique Enríquez de la aceptación de las treguas de Majano, una vez que éste retornó de su campaña naval: AGS, Patronato Real, leg. 12, doc. 39, f. 307v; apéndice documental $\mathrm{n}^{\circ} \mathrm{V}$.

46. AGS, Contaduría Mayor del Sueldo ( $1^{\mathrm{a}}$ serie), leg. 53, f. 40.

47. Fernández de Navarrete 1858, p. 553.

48. Según Gago-Jover 2002, p. 65, el ballener era un tipo de navío largo, abierto y bajo de costados, usado generalmente para acciones bélicas. Los había de diversos tamaños y, además, podían propulsarse a vela o remo.

49. AGS, Contaduría Mayor del Sueldo ( $1^{\mathrm{a}}$ serie), leg. 53, f. 40.

50. Para una visión general del reclutamiento de tripulantes durante el siglo XV, véase: Aznar Vallejo 2006, pp. 337-338.

51. AGS, Contaduría Mayor del Sueldo ( $1^{\mathrm{a}}$ serie), leg. 53, f. 40. En las tierras de behetría, desde siglos atrás, los naturales de dichas comarcas tenían la obligación de servir como galeotes en las armadas reales: Estepa Díez 2006, pp. 13-14.

52. García Isaac, Idáñez Vicente 2018, p. 84. 
su profesionalidad, es probable que fuera nula o escasa. En 1481, con motivo de la flota que armaron los Reyes Católicos para socorrer a la población italiana de Otranto del ataque de los turcos, este servicio personal de galeotes fue sustituido por la entrega de una carga económica. Según el cronista Fernando del Pulgar:

E porque los moradores de las Behetrías no tienen el uso de navegar, por la gran distancia que hay de los lugares do moran a los puertos de la mar, ficieron composición con aquellos dos comisarios, de les dar cierta suma de maravedis, con la qual tomasen otros galeotes de las villas e lugares que son cerca de puertos de mar, y ellos fuesen libres de ir en el armada... ${ }^{53}$

Esta misma falta de pericia marinera, en nuestra opinión, debía de ser igual cinco décadas atrás. Por ese motivo, Juan II permitió que en Sevilla pudieran enrolarse como galeotes aquellos que lo deseasen, cobrando la misma suma que recibían los de behetrías, 1. 000 maravedís. Sin embargo, pocos fueron los profesionales de la mar que acudieron a la llamada de su rey para servir en la armada. Por lo tanto, Juan II se vio obligado a exigir a los principales municipios del arzobispado de Sevilla y obispado de Córdoba, que hicieran un repartimiento de galeotes ${ }^{54}$. En el Archivo Municipal de Sevilla, se conservan las cuentas del repartimiento de 150 galeotes realizados en Sevilla y su tierra. La capital hispalense se encargó del reclutamiento de un tercio del total (50 galeotes), la comarca de la Campiña 25, las comarcas del Aljarafe y la Ribera 33, la comarca de la Sierra de Aroche 27 y la Sierra de Constantina $15^{55}$. Además de estas noticias, se sabe que ciertos labradores que se dirigían a trabajar en la siega de los campos jerezanos, fueron reclutados como galeotes por la fuerza, lo que disgustó a las autoridades de dicha población ${ }^{56}$.

Sobre el número de ballesteros y hombres de armas embarcados ${ }^{57}$, se sabe que de los primeros había una dotación total de 30 en cada galera, exceptuando la del almirante, donde el número total ascendía hasta 50 ballesteros. Por lo tanto, el número total de ballesteros de la armada ascendía hasta los 620 efectivos. Cada uno, además, cobró por su servicio 1.200 maravedís. Así pues, en total se gastaron, aproximadamente, 720.000 maravedís para pagar a todos los ballesteros. Referente a los hombres de armas, se reclutaron 10 para cada galera, excepto la capitana del almirante, donde la dotación de los mismos ascendió hasta 20. Por lo tanto, el número de hombres de armas reclutados para las galeras fue de 210 efectivos. Su sueldo, a diferencia del que recibieron los galeotes y ballesteros, que incluía el tiempo total de estancia en la armada, se pagaba diariamente, percibiendo cada uno de ellos 10 maravedís por día. Los ballesteros y hombres de armas embarca-

53. Rosell 1953, p. 358.

54. Archivo Municipal de Sevilla (en adelante AMS), Papeles del Mayordomazgo, 1429, $\mathrm{n}^{\circ}$ 130; apéndice documental $\mathrm{n}^{\mathrm{o}}$ III.

55. AMS, Sección XVI, n ${ }^{\circ} 104$.

56. AMJF, Acta Capitular de 1430, f. 22v; Orellana González 2015, p. 152.

57. AGS, Contaduría Mayor del Sueldo ( $1^{\mathrm{a}}$ serie $)$, leg. 53, f. 40. 
dos en las naos y balleneres, según el testimonio de las cuentas, cobraron lo mismo que los que sirvieron en las galeras ${ }^{58}$.

Según un testimonio de las actas capitulares jerezanas, la convivencia de las gentes de mar, ante la tardanza de la partida de la flota, no debió ser muy pacífica. Por tal motivo, el concejo de Jerez de la Frontera, el 21 de marzo de 1430, estableció que:

Todos los ballesteros, e galeotes e otros onmes que han de yr en las galeas, que se vayan a ellas, e non estén en esta çibdad nin en sus términos. E sy fueren fallados, pasado tercer día, que sepan que darán a cada uno çinquenta açotes ${ }^{59}$.

En cuanto al resto de miembros de las respectivas tripulaciones, las fuentes no aportan muchos más datos. Al parecer en cada galera viajaba un escribano, que escriviese las tomas y presas que se fizyesen para la dicha flota, quienes respondían directamente ante el escribano de la armada del rey. Esta medida no contó con el visto bueno del almirante, quien no lo consintió y, en su lugar, pretendía poner sus propios escribanos. El rey, no obstante, falló a favor del escribano de la armada, pues, era imprescindible que se controlase con total escrupulosidad el total de ganancias que perteneciesen al rey y al almirante, fijadas, en dos tercios de las mismas para el rey y la parte restante para el almirante ${ }^{60}$. También, se sabe que se intentó reclutar a cirujanos de los municipios próximos a Sevilla, como fue el caso del concejo de Jerez de la Frontera, donde las autoridades municipales denegaron a sus sanitarios acudir a servir en las galeras reales ${ }^{61}$.

Para completar este apartado, merece una especial atención señalar la única noticia referente al abastecimiento de alimentos para la flota. A este respecto, se sabe que el almirante Fadrique Enríquez escribió en marzo de 1430 a las autoridades jerezanas, pidiendo que ayudasen en todo lo posible a Juan de $\mathrm{Caso}^{62}$, a quien se denomina como tenedor de los hornos del bizcocho, aunque sin especificar de qué población ${ }^{63}$.

\section{ORdenANZAS NAVALES DEL ALMIRANTE FADRIQUe ENRÍQUEZ}

Entre las principales fuentes documentales que han llegada hasta nuestros días sobre esta campaña naval, destacan especialmente las ordenanzas navales que re-

58. “Asý la gente que en ellas yva, fue pagada asý conmo la de las galeas...” AGS, Contaduría Mayor del Sueldo (1 ${ }^{\mathrm{a}}$ serie), leg. 53, f. 40.

59. AMJF, Acta Capitular de 1430, f. 22v; Orellana González 2015, p. 152.

60. AGS, Contaduría Mayor del Sueldo ( $1^{\mathrm{a}}$ serie), leg. 53, f. 40.

61. AMJF, Acta Capitular de 1430, f. 2v; Orellana González 2015, p. 146.

62. Con seguridad, este personaje debía ser familiar directo, tal vez hermano o primo, de Alfonso Guillén de Caso, tenedor de los hornos del bizcocho de Sevilla.

63. AMJF, Acta Capitular de 1430, f. 20r ( $2^{a}$ foliación); Orellana González 2015, p. 151. Apéndice documental $\mathrm{n}^{\circ}$ II. Probablemente, los hornos de los que era responsable se encontraban en la propia Jerez de la Frontera. 
dactó el almirante Fadrique Enríquez para el buen gobierno de la armada ${ }^{64}$. Como ya señaló Francisco Javier García de Castro, este ordenamiento es excepcional, pues, además de las escuetas disposiciones establecidas en el título XXIV de la Segunda Partida, esta ordenanza es la única que se conoce en toda la Baja Edad Media castellana para poder estudiar la administración de justicia, las técnicas de combate, el reparto del botín y las demás disposiciones para la administración de la armada ${ }^{65}$. Los 39 capítulos que conforman las ordenanzas, pueden agruparse de la siguiente manera:

Tabla 1. Ordenanzas del almirante Fadrique Enríquez (1430).

\begin{tabular}{|c|l|}
\hline NÚMERO DE CAPÍTULO/OS & \multicolumn{1}{|c|}{ DISPOSICIONES } \\
\hline I & Preeminencia de la galera del almirante \\
\hline II-IX & Sistema de luces para guiar a la flota \\
\hline X & Modo de anclar las naves \\
\hline XI & $\begin{array}{l}\text { Preeminencia del almirante a la hora de desembarcar } \\
\text { en tierra }\end{array}$ \\
\hline XII & $\begin{array}{l}\text { Prohibición de recoger agua o leña sin la autorización } \\
\text { del almirante }\end{array}$ \\
\hline XIII-XIV & Preeminencia de los trompeteros del almirante \\
\hline XV-XVIII & Combate contra naves enemigas \\
\hline XIX & Reparto del botín \\
\hline XX-XXI & $\begin{array}{l}\text { Entrada de la tripulación en otras embarcaciones de } \\
\text { amigos y enemigos }\end{array}$ \\
\hline XXII-XXIII & Señales durante el combate \\
\hline XXIV & $\begin{array}{l}\text { Disposición sobre el modo de efectuar aguadas y reco- } \\
\text { gida posterior de los tripulantes }\end{array}$ \\
\hline XXV & $\begin{array}{l}\text { Pena para los cómitres de la armada por romper los } \\
\text { remos de las galeras amigas }\end{array}$ \\
\hline XXVI & $\begin{array}{l}\text { Prohibición a los cómitres de vender al por menor tras } \\
\text { la caída del sol }\end{array}$ \\
\hline XXVII & $\begin{array}{l}\text { Prohibición de tomar embarcaciones pequeñas por la } \\
\text { fuerza }\end{array}$ \\
\hline XXVIII & $\begin{array}{l}\text { Prohibición de encender luces por la noche las naves } \\
\text { de la armada excepto la del almirante. }\end{array}$ \\
\hline XXXX & $\begin{array}{l}\text { Prohibición a los tripulantes de desembarcar en puer- } \\
\text { tos amigos con armas }\end{array}$ \\
\hline Sistemas de luces durante el combate \\
\hline XXXII & $\begin{array}{l}\text { Prohibición de enviar hombres a tierra sin permiso del } \\
\text { almirante }\end{array}$ \\
\hline Ordenanzas contra el juego \\
\hline XXII & \\
\hline XXII &
\end{tabular}

64. Las ordenanzas se encuentran publicadas en: Fernández de Navarrete 1858, pp. 554-564.

65. García de Castro 2014, pp. 70-72. Véase también: Aznar Vallejo 2009, p. 189. 


\begin{tabular}{|c|l|}
\hline NÚMERO DE CAPÍTULO/OS & \multicolumn{1}{c|}{ DISPOSICIONES } \\
\hline XXXV & $\begin{array}{l}\text { Normas para aproximarse una galera cualquiera a la } \\
\text { del almirante }\end{array}$ \\
\hline XXXVI & Prohibición a los cómitres de poder ir a tierra \\
\hline XXXVII-XXXIX & $\begin{array}{l}\text { Disposiciones generales sobre la redacción de las or- } \\
\text { denanzas y penas para aquellos que no respetasen los } \\
\text { capítulos redactados por el almirante }\end{array}$ \\
\hline
\end{tabular}

Fuente: Fernández de Navarrete 1858, pp. 554-564 ${ }^{66}$.

En cuanto a la fecha de redacción de la ordenanza, no se sabe cual pudo ser. Según Francisco Javier García de Castro, probablemente, estas disposiciones redactadas por el almirante no fueran más que una copia o una matización de otras anteriores ${ }^{67}$. Sea como fuere, con este ordenamiento, el almirante de Castilla contaba con una herramienta excepcional para el buen gobierno de la armada. En ello, es donde radica la importancia capital de este ordenamiento, pues, como ya hemos mencionado anteriormente, es algo único dentro la historia naval castellana de la Baja Edad Media.

\section{CAMPAÑA BÉLICA}

Una vez que la flota organizada en Sevilla estuvo preparada, Fadrique Enríquez se apresuró a partir rumbo a Cartagena, principal y único puerto castellano de gran tamaño en el Mediterráneo ${ }^{68}$. Como indica Álvar García de Santa María, el almirante se adelantó hasta el puerto de Cádiz, en donde esperó al resto de galeras sevillanas y a la flota del Cantábrico, cuya dirección hasta las costas andaluzas había sido encomendada a Juan de Tovar ${ }^{69}$. Según dicho cronista, la partida de Fadrique de Sevilla fue en el mes de julio. En este punto, la información no concuerda con la documentación conservada en el Archivo Municipal de Elche. En efecto, en una carta enviada por las autoridades municipales oriolanas a los municipios de Elche y Alicante, que ya mencionamos anteriormente, se indicaba que los espías oriolanos en el puerto de Cartagena informaron de la llegada de la flota castellana

66. García de Castro 2014, pp. 71-72, ofrece una organización un tanto distinta de los capítulos que conforman las ordenanzas navales del almirante Fadrique Enríquez. No obstante, la que nosotros hemos realizado, creemos que es más coherente a la hora de agrupar los distintos apartados, atendiendo de una forma rigurosa a la finalidad concreta de los mismos y sus similitudes con otros.

67. García de Castro 2014, p. 68.

68. Curiosamente, los espías aragoneses debieron informar a finales de abril a Alfonso V que la flota castellana que se había formado era bastante considerable. Por tal motivo, semanas antes de su partida, el rey de Aragón escribió al consell de Valencia el 9 de mayo, ordenándoles que estuvieran preparados para hacer frente a tan poderosa armada: Archivo del Reino de Valencia (en adelante ARV), Cancillería Real, reg. 233, ff. 62v-63r.

69. García de Santa María 1892, pp. 250-251. El cronista, además, menciona que en Cádiz el almirante examinó la carga de cinco galeras ancladas en dicho puerto, para comprobar que no llevasen ningún tipo de suministros al enemigo aragonés. 
el día 21 de junio ${ }^{70}$. En nuestra opinión, creemos que lo correcto es aceptar como válida la cronología de la misiva oriolana, pues, al tratarse de una información comprobada in situ por los propios agentes oriolanos en Cartagena, consideramos que es más verídica que la información que pudo haber recibido el cronista.

No obstante, no se debe descartar que, cuando el grueso de la flota llegó a Cartagena, Fadrique todavía estuviese en tierras andaluzas, ultimando, quizás, los últimos preparativos bélicos o esperando instrucciones regias. En efecto, la flota castellana anclada en Cartagena no organizó ninguna expedición contra las costas alicantinas por espacio de dos meses. Probablemente, esta inactividad de la armada fue debida a la ausencia del almirante y, por lo tanto, de cualquier tipo de órdenes o instrucciones a este respecto. Hay que tener en cuenta, además, que la diplomacia de ambas coronas ya estaba trabajando en la firma de una tregua que pusiera fin a las hostilidades bélicas. Dicho acuerdo, finalmente, se alcanzó en Majano, el 16 de julio de $1430^{71}$.

Según Álvar García de Santa María, al poco de llegar a Cartagena, el almirante recibió la noticia de la firma de las treguas de Majano ${ }^{72}$. Gracias a la documentación del Archivo Municipal de Murcia, se saben las fechas y los nombres de los posibles emisarios reales que transmitieron al almirante la noticia y el traslado del texto de la tregua. El encargado de entregar al concejo de Murcia y, presumiblemente, al almirante de Castilla, las respectivas cartas de Juan II anunciando la firma de las treguas fue Juan de Barros, escudero de caballo del rey de Castilla, quien llegó a Murcia el 7 de agosto ${ }^{73}$. Inmediatamente, puso rumbo a Cartagena. Para este pequeño trayecto, contó con la inestimable ayuda del concejo murciano, quien le proporcionó una mula para poder continuar su viaje hasta la ciudad portuaria, pues, la suya se encontraba enferma ${ }^{74}$. Algunos días después, llegó a Murcia, con el traslado de los capítulos de las treguas, Ferrando Díaz de Ávila, escribano del rey ${ }^{75}$. Al poco de llegar a dicha ciudad, hubo de pedir ayuda a las autoridades murcianas:

70. AME, a7, ff. $37 \mathrm{v}-38 \mathrm{v}$.

71. Ryder 1992, pp. 217-218. La duración de las treguas se estableció en cinco años.

72. García de Santa María 1892, p. 251.

73. AMM, AC53, f. 15r. Curiosamente, en tierras oriolanas se conoció la noticia de la firma de las treguas con varios días de antelación con respecto a Murcia. Véase a este respecto la carta enviada por el consell de Orihuela a las autoridades ilicitanas y alicantinas el 28 de julio de 1430: Archivo Municipal de Orihuela (en adelante AMO), A-20, ff. 307v-308r.

74. AMM, leg. 4305, $\mathrm{n}^{\circ}$ 9, f. 14v. La mula era propiedad de Juan Gutiérrez y su alquiler, durante dos días, costó 24 maravedís. El 12 de agosto ya estaba dispuesto a partir para la corte, aunque, según su testimonio, "non tenía dineros algunos con que fuese, que le avían fallecido, e avía gastado, los maravedís quel dicho señor rey le avía mandado dar para su pensión e mantenimiento". Para ayudarle, las autoridades murcianas le entregaron 300 maravedís: AMM, AC53, f. 16r.

75. Este personaje, además, en el momento en que Fadrique Enríquez, una vez terminada la guerra, tuvo que jurar el cumplimiento de los capítulos acordados en Majano, fue el representante enviado por Juan II de Castilla a la corte aragonesa para entregar la confirmación del almirante. Por lo tanto, es más que probable que cuando se encontraron en Cartagena, el almirante le pidiese que él fuera el encargado de entregar dicha jura, una vez que hubiera terminado la campaña naval: AGS, Patronato Real, leg. 12, doc. 39, f. 307r. 
E en el dicho conçejo paresçió Ferrando Díaz de Ávila, escrivano del rey nuestro señor, el qual, troxo los capitulos de las treguas de los çinco años corrientes, entre Castilla e Aragón, firmadas. E dixo a lo dichos señores conçejo (...) por estar trabajada e cansada la bestia que el traýa, les avía pedido que le mandasen dar otra bestia, para en que fuese a la çibdad de Cartajena, a llevar allá los dichos capitulos de las dichas treguas, a les fazer publicación d'ellos, segund que por el dicho señor rey le fue mandado (...) la qual, el tovo en yda, e venida, e estada e estada en la dicha çibdad de Cartajena, çinco días... ${ }^{76}$

Como indica Álvar García de Santa María, el almirante se enojó al conocer la firma de las treguas ${ }^{77}$. Por ello, decidió aprovechar las semanas que restaban para que diese comienzo la tregua para realizar alguna acción bélica que pudiera reportar cierto beneficio a la armada. Sin duda alguna, tras haber estado la flota anclada en Cartagena durante dos meses, el desánimo y la desidia debía reinar entre los tripulantes. Por lo tanto, Fadrique Enríquez no demoró sus planes y preparó la estrategia para arrasar el primer objetivo señalado, que no fue otro que la villa de Elche.

Pero ¿organizaron algún ningún tipo de estrategia los oficiales aragoneses para frenar a la flota castellana? En nuestra opinión, al comienzo de la contienda, ni el rey Alfonso V ni el resto de poderes del territorio de la Corona de Aragón creyeron que este conflicto pudiera tener grandes dimensiones navales. Prueba de ello, es la negativa de Barcelona, señora de la villa de Elche, a enviarles un cargamento de pólvora a comienzos del otoño de 1429, pues, la ciudad condal había organizado una flotilla de tres naus grossas contra cossaris, razón por la cual, necesitaban toda la pólvora disponible para dicha empresa ${ }^{78}$. Solo cuando los informes de los espías revelaron la magnitud de la flota castellana, se tomaron algunas medidas defensivas.

Por ello, a comienzos de junio, Alfonso V ordenó al consell de Valencia que dieran toda la ayuda posible a las naves que se estaban armando en la ciudad del Turia para repeler a las galeras castellanas ${ }^{79}$. Sin embargo, según se desprende de la documentación acerca de estas galeras, o bien su número era insignificante, o simplemente se dedicaron a vigilar las aguas próximas a la capital valenciana ${ }^{80}$. En tierras de la gobernación de Orihuela, concretamente en el puerto de Alicante, solo hemos encontrado una única noticia referente al armamento, a finales de agosto,

76. AMM, AC53, f. 18r. La mula que le prestaron las autoridades murcianas era propiedad de Bartolomé Martínez y, el alquiler del animal, ascendió a un total de 45 maravedís. Por otro lado, el concejo le pagó un total de 1.000 maravedís por la copia de los capítulos de las treguas. AMM, AC53, f. $18 \mathrm{v}$.

77. García de Santa María 1892, p. 251.

78. AME, 480 13. Sobre esta expedición naval barcelonesa, véase: Unali 2007, pp. 65-66.

79. ARV, Cancillería Real, reg. 233, f. 72r. Véase también, a este respecto, las cartas enviadas al tesorero real y a los patrones de las galeras ancladas en Valencia: ARV, Cancillería Real, reg. 233, ff. $75 \mathrm{rv}$.

80. El consell de Valencia, en cambio, si creyó que la flota de Castilla podía ser una seria amenaza. Por tanto, el 23 de agosto ordenaron que la ciudad estuviera bien guarnecida ante un inminente ataque castellano: Díaz Borrás 2002, p. 77. 
de una nave corsaria, aunque, al parecer, destinada exclusivamente a capturar pescadores murcianos en las aguas del Mar Menor ${ }^{81}$. Por lo tanto, la flota castellana no contaba con ningún rival, lo que en principio, debería favorecer los planes militares del almirante Fadrique Enríquez.

A finales de agosto zarpó la armada castellana, rumbo al cabo del Aljup, principal fondeadero ilicitano ${ }^{82}$. El día 25, una jornada antes de que se iniciase el ataque contra Elche, la flota ya se encontraba anclada en dicho cabo. Ante esta situación, las autoridades alicantinas, temerosas de ser su ciudad el objetivo principal de los castellanos, pidieron ayuda al consell de Orihuela ${ }^{83}$. De hecho, el historiador del siglo XVI Jerónimo Zurita, en su obra Anales de la Corona de Aragón, indicó que Alicante fue la plaza atacada por la armada castellana ${ }^{84}$. La misma noticia recogió el cronista oriolano del siglo XVII Pedro Bellot en sus Anales de Orihuela ${ }^{85}$. Sin embargo, como ya hemos mencionado antes, la plaza seleccionada por el almirante para iniciar el primer gran ataque de la flota castellana en toda la campaña fue Elche ${ }^{86}$.

Aunque la documentación ilicitana es muy pródiga en cuento a testimonios sobre el ataque ${ }^{87}$, la mejor fuente para conocer el mismo es una misiva que el consell de Elche envió a las autoridades barcelonesas el 31 de agosto $^{88}$. En dicha carta, se indica como un contingente de 2.500 castellanos $^{89}$, al mando de Juan de Tovar ${ }^{90}$, lanzaron un asalto contra los arrabales y la morería de Elche. Sin embargo, la milicia concejil consiguió repeler la agresión, aunque no pudieron evitar que los castellanos quemasen algunas casas. Tras detener la embestida castellana, la hueste ilicitana los persiguió hasta el Pinatar ${ }^{91}$, localización próxima al cabo del Aljup,

81. AMM, AC53, f. 20v.

82. Sobre la importancia de este puerto en la Baja Edad Media, véase: Hinojosa Montalvo 1989, pp. 311-324.

83. AMO, A-20, f. 322v. Ante esta posible amenaza, las autoridades oriolanas enviaron un contingente de 100 soldados para ayudar en la defensa de Alicante: Almúnia 2008, p. 107.

84. Zurita 2007, pp. 769-770.

85. Bellot 2001, pp. 340-341.

86. Además de los autores de época moderna anteriormente mencionados, también algunos estudiosos modernos ignoraron que Elche fue la plaza atacada, no Alicante. Así lo recogen, entre otros, Calderón Ortega 2003, p. 87 y García de Castro 2014, p. 193, quienes siguen directamente el testimonio de Jerónimo Zurita. Algunos años atrás, Martín de Riquer, en la primera edición de 1984 de su biografía de Pere Maça, gobernador general de Orihuela, ya indicó que la plaza objeto del ataque castellano fue Elche. Véase a este respecto: Riquer 2004, p. 111.

87. Entre otras noticias, véase el testimonio del ataque en las actas de la sesión del concejo del 31 de agosto: AME, a7, f. 117v. Véase también la extensa carta enviada a Alfonso V ese mismo día, en donde, además de la noticia del ataque castellano, se relatan otros hechos: AME, a7, ff. 119v-124v.

88. AME, a7, ff. $124 \mathrm{v}-126 \mathrm{v}$; apéndice documental $\mathrm{n}^{\circ} \mathrm{IV}$.

89. En nuestra opinión, tal cantidad de efectivos nos parece un tanto desproporcionada. Quizás, incluyendo en el mismo a contingentes de marinería no profesional en el arte de la guerra, tal vez pudiera alcanzarse dicha cifra, o una más aproximada.

90. Es curioso que la operación fuera dirigida no por el almirante, sino por su segundo en el mando. Tal vez, Juan de Tovar contara con una mayor experiencia bélica que el almirante, o simplemente, éste último creyó más oportuno quedarse al frente de las unidades que todavía seguían embarcadas.

91. Desconocemos la localización exacta de este topónimo, aunque puede que se trate del paraje conocido en la actualidad como "playa y salinas del Pinet", en el término municipal de Elche, a poca distancia del cabo del Aljup. 
donde dieron muerte a unos cuentos y, según indicaron a las autoridades barcelonesas, han presa e hauda certa desferra, ço es, armes, cuyraçes, balestes, paveses, glavis e altres armes, les quals, son en la dita vostra vila ${ }^{92}$. Ese mismo día, el gobernador general de Orihuela, Pero Maça de Liçana, llegó desde Alicante con una compañía armada, ahuyentado al resto de efectivos castellanos que aún quedaban en tierra. Los prisioneros, fueron encerrados en la torre del cabo del Aljup.

La derrota de la hueste castellana no desanimó al almirante de Castilla. Al contrario, como se verá ahora, puso sus miras en un objetivo más ambicioso que la costa alicantina. Pero Maça, por el contrario, obtuvo una espléndida felicitación por parte del rey Alfonso $\mathrm{V}^{93}$, quien, desde Valencia ${ }^{94}$, en pocos días, supo las nuevas de la derrota de los castellanos. Sin embargo, Pero Maça no descuidó la vigilancia de la costa. Es más, tras la partida de las naves castellanas, su itinerario fue detenidamente registrado por los oficiales de Pero Maça, quien, el 14 de septiembre, informó a las autoridades oriolanas y a las ilicitanas de que la armada de Castilla se encontraba frente a Cullera ${ }^{95}$. Un día después, el gobernador volvió a escribir a Orihuela, avisándoles que algunas de las naves castellanas se habían rezagado del resto de la flota y podían ser una amenaza, todavía, para la costa alicantina, pues, según la misiva:

Una galera e hun berganti eren stats d'avant Calp. E hum hom del dit berganti, qui es de Calp natura ${ }^{96}$, is que entera, e h'avisat los del dit loch de Calp, com totes les galeres seran prestament en les part d'eça, menaçant, sobre tots, los altres lochs de la dita vila d'Alacant... ${ }^{97}$

Sin embargo, si bien el marinero oriundo de Calpe no sabía las intenciones reales del almirante, o bien se trataba de un agente para desinformar a las autoridades valencianas encargadas de vigilar la costa, lo cierto es que el objetivo del almirante era dirigirse hacia el Reino de Mallorca, creyendo, quizás, que las costas de dicho territorio estarían menos vigiladas. Buscando vientos favorables para cruzar el mar, la flota castellana volvió a descender hasta Villajoyosa, donde fue avistada por los hombres de Pero Maça el 19 de septiembre ${ }^{98}$. En una travesía que no debió de prolongarse más de dos días, llegaron a la isla de Ibiza,

92. Parte del armamento que capturaron los vecinos de Elche fue depositado algunos meses después, concretamente en febrero de 1431, en la iglesia de Santa María de aquella población, con la pertinente autorización de Ginés Bataller, vicario de la villa: AME, a7, ff. 286v-287r. Posteriormente, dicho material fue subastado en una almoneda pública organizada por los oficiales municipales Joan Martí y Joan d'Aliaga: AME, b 339, f. 55r.

93. ARV, Cancillería Real, reg. 233, ff. 88v-89r.

94. Según Zurita 2007, p. 769, el rey de Aragón llegó a la capital valenciana el 26 de agosto, el mismo día de la derrota de los castellanos.

95. AMO, A-20, f. 328r; AME, a7, ff. 145v-146r.

96. Curioso que entre los miembros de la marinería hubiera un valenciano de Calpe. Probablemente, no se trate de un caso aislado y, por lo tanto, es posible que hubiera más tripulantes oriundos de tierras de la Corona de Aragón.

97. AMO, A-20, f. 329r.

98. AME, a7, f. 156r. 
donde tuvo lugar el último intento de obtener botín, antes de que las treguas entrasen vigor ${ }^{99}$.

Sobre el ataque a Ibiza, la única fuente representativa con la que contamos es el testimonio de Álvar García de Santa María. En la narración de dicho literato, la hueste del almirante llegaba hasta los 3.000 efectivos $^{100}$. La cantidad de daños que causaron los hombres de Fadrique Enríquez, según el cronista, ascendieron a más de 400.000 florines $^{101}$. Según el texto del pleito homenaje tomado al almirante castellano, la armada también causó daños en las islas de Mallorca y Menorca ${ }^{102}$. En nuestra opinión, es bastante probable que la flota se dividiese en varias unidades, actuando cada una de ellas en una isla diferente. Sin embargo, con total seguridad, la isla de Ibiza fue la que sufrió con mayor intensidad los estragos de los marinos castellanos ${ }^{103}$. En este ataque anfibio, el almirante si participó, aunque fue herido de un disparo de ballesta en el hombro, mientras dirigía un ataque contra la atarazana ibicenca ${ }^{104}$. Tras este nuevo revés, el almirante pretendió atacar la isla de Mallorca ${ }^{105}$. No obstante, puesto que ya quedaban pocos días para que diese comienzo la tregua, a finales de septiembre, Fadrique Enríquez ordenó a la flota que volviese a tierras castellanas ${ }^{106}$. Curiosamente, en un asiento del libro de cuentas del mestre reyal de les obres de fusta de Mallorca de ese año, referente a la instalación de manteletes y de una pasarela en el castillo real de Palma, se recogió la siguiente noticia:

Los quals mantalets e andador foren fetes per defensio del dit castell, per raho del estol de galeas del rey de Castella, que en lo mes de setembre del present any arribaren demunt lo port de Portupi; e algunes vengueren demunt lo cap del Mollo, port de la present ciutat... ${ }^{107}$

El itinerario de retorno de la armada se puede reconstruir con cierta precisión. El 4 de octubre, ya se encontraba en aguas próximas a Elche, pues, los vigías del consell dieron aviso ese día a las autoridades municipales del avistamiento de

99. Las autoridades baleares debían de estar al tanto de la incursión naval castellana. No obstante, apenas se tomaron medidas para reforzar las defensas insulares. Véase a este respecto: Bonnín Femenías 2011, p. 417.

100. De nuevo, al igual que el combate de Elche del 26 de agosto, nos parece un número desproporcionado de combatientes.

101. García de Santa María 1892, p. 251

102. Fernández de Navarrete 1858 , p. 553. En este mismo texto, además, se menciona que en esos días fueron capturadas en los mares baleares dos galeras. La primera fue la de Mosén Grao, embajador de Alfonso V en la corte portuguesa. La segunda, propiedad de Mosén Villamares, fue capturada por la flota castellana cuando pretendía anclar en el puerto de Ibiza, de retorno de un viaje en Berbería.

103. No obstante, hay que tener en cuenta que la campaña balear de Fadrique Enríquez no hubo de durar más de ocho o nueve días. Por lo tanto, los ataques contra las islas de Mallorca y Menorca debieron de ser insignificantes.

104. García de Santa María 1892, p. 251.

105. Ibid., pp. 251-252.

106. Fernández de Navarrete 1858, p. 553.

107. Archivo del Reino de Mallorca, Real Patrimonio, 3519, f. 50r. 
la flota castellana ${ }^{108}$. Algunos días atrás, los representantes oriolanos enviados a Valencia ante el rey Alfonso V, habían transmitido al monarca aragonés el temor a un ataque castellano contra Guardamar ${ }^{109}$. El almirante de Castilla, sin embargo, no tenía ninguna intención de atacar ningún dominio del rey de Aragón. Su único objetivo, en ese momento, no era otro que el de volver a tierras andaluzas, para comenzar el proceso de desarme de la flota. El 3 o 4 de octubre, al parecer, algunos de los navíos entraron en el puerto de Cartagena para aprovisionarse, rápidamente, de harina para la fabricación de bizcocho. Entre las cargas que tomaron, o confiscaron, se encontraba una perteneciente al oriolano Gonçalvo Agudo. Ante este hecho, el 5 de octubre, el consell de Orihuela no dudó en pedir explicaciones al concejo de Cartagena, quienes, justificaron este hecho afirmando que lo capita $^{110}$ de les fustes lo li auria preses e levat ${ }^{111}$.

La armada continuó su rumbo hasta el Puerto de Santa María, donde el almirante decidió que las tripulaciones pasaran el invierno ${ }^{112}$. Probablemente, el almirante se adelantara al resto de la flota, pues ya se documenta su presencia en Cádiz el 10 de octubre, fecha en que juró aceptar y cumplir las treguas alcanzadas en Majano ${ }^{113}$, tal como le pidió Juan II, en una carta datada el 4 de septiembre de 1430 , una vez que hubiera dada por finalizada la campaña ${ }^{114}$. Durante los meses invernales, los patrones de las galeras cometieron ciertos estragos en Sevilla, lo que se tradujo en una airada queja de las autoridades municipales al almirante ${ }^{115}$. A finales del invierno, ya en el año 1431, por orden del rey, el almirante despidió a todas las naves cantábricas excepto a las galeras santanderinas, las cuales, junto con las sevillanas, fueron armadas de nuevo para combatir contra los granadinos ${ }^{116}$.

\section{CONCLUSIONES}

Para finalizar, creemos conveniente resaltar los aspectos más interesantes de la flota castellana armada en 1430 contra Aragón. En primer lugar, debido a la numerosa documentación que publicó en el siglo XIX Martín Fernández de Navarrete, se puede reconstruir de modo excepcional los procedimientos regios para ordenar el armamento de una escuadra de guerra, algo que, por desgracia, no se conoce con tanta precisión en otras campañas navales anteriores. En segundo lugar, gracias

108. AME, a7, f. 186v.

109. AMO, A-20, f. 345r.

110. Quizás se refiera el documento a Juan de Tovar.

111. AMO, A-20, f. 346r.

112. Fernández de Navarrete 1858, p. 553.

113. AGS, Patronato Real, leg. 12 , doc. 39 , f. $307 \mathrm{v}$.

114. AGS, Patronato Real, leg. 12, doc. 39, f. 307v; apéndice documental $\mathrm{n}^{\circ} \mathrm{V}$.

115. ADA, C. 77, n⿳ 26; Calderón Ortega 2003, pp. 348-349.

116. Fernández de Navarrete 1858, p. 553. Sobre la campaña naval de 1431 contra el Reino de Granada, véase: García de Castro 2014, p. 193. Según Sánchez Saus 1987, p. 399, en la campaña granadina actuaron el mismo número de efectivos que en la campaña aragonesa, incluidas las naos y balleneres cantábricos. 
a las cuentas de las galeras conservadas en el Archivo General de Simancas, se puede precisar con gran seguridad el número de galeotes y de ballesteros y hombres de armas embarcados en las galeras, algo que tampoco suele ser habitual en documentación de épocas anteriores, debido a la crónica escasez de fuentes documentales en los archivos castellanos para la esta época. Por último, las fuentes de los distintos archivos valencianos que hemos podido consultar, arrojan una visión totalmente renovada de esta campaña. En efecto, gracias a dicha documentación, se han podido conocer aspectos totalmente desconocidos de la ofensiva mediterránea del almirante Fadrique Enríquez contra la Corona de Aragón.

Por todo ello, queremos hacer una especial llamada de atención sobre la importancia de los archivos valencianos como fuentes de gran valor para el conocimiento de la historia medieval castellana. A este respecto, consideramos que la visión que aportan los datos contenidos en ellos sobre la armada castellana de 1430, modifican por completo la percepción que de dicha expedición naval se tenía, pues, hasta el momento, cualquier aproximación a la misma se había realizado casi exclusivamente con fuentes castellanas ${ }^{117}$. Por último, también queremos reseñar la importancia de los pequeños, aunque sumamente interesantes, datos que hemos podido obtener en los archivos municipales de Jerez de la Frontera y Murcia. Hasta donde llega nuestro conocimiento, nadie, o muy poca gente, había pensado en revisar dichos fondos para documentarse sobre la expedición de Fadrique Enríquez y, como se ha podido comprobar, han sido realmente vitales. Por ello, esperamos y, así lo creemos, que todos aquellos interesados en el estudio de la historia naval castellana, se atreverán a sumergirse en los fondos de todos estos archivos que hemos mencionado anteriormente.

\section{APÉNDICE DOCUMENTAL}

1427, diciembre, 6, [Segovia $\left.{ }^{118}\right]$.

Albalá de Juan II dirigido a Juan de Silva, notario mayor del Reino de Toledo, ordenándole la construcción de unas nuevas atarazanas y cinco galeras en la villa de Santander.

AHNob, Cifuentes, Cp. 417, doc. 10.

Yo el rey fago saber a vos Johan de Sylva, mi vasallo e mi notario mayor del Reygno de Toledo, que mi merçed e voluntad es que se fagan en la mi villa de Santander las taraçanas que yo, por otra mi carta, ove mandado fazer en la dicha villa, para en que puedan estar seys galeas. E que las fagades fazer vos, el dicho Juan de Sylva, en el logar e espaçio que agora están las $\beta$ quatro galeas que Gonçalo Gonçáles de Setién, por mi mandado, puso dentro de la dicha villa, e en los logares, e solares e espaçios que están más çercanos del dicho

117. Principalmente, la documentación publicada por Martín Fernández de Navarrete y la crónica de Juan II escrita por Álvar García de Santa María.

118. Aunque en el documento no se indica el lugar donde fue expedido, se sabe que ese día Juan II se encontraba en Segovia. Véase a este respecto: Cañas Gálvez 2007, p. 229. 
logar do están las dichas galeas, así de parte de tierras do están las dichas galeas, fasta el muro de la çerca de la dicha villa, conmo en las costaneras que son, de la una parte, fasta la rua de Sant Françisco, e de la otra parte, fasta la calle que dizen de la carneçería vieja, e por delante, fasta la calle que dizen de la rua de La Puente. E otrosý, es mi merçed, e mando, que fagades tomar dos $/^{6}$ omes buenos, maestros de carpentería, e otros dos maestros de albañería e cantería. E sobre juramento que d'ellos, primeramente, fagades resçebir en forma devida, por ante Ferránd Sánchez de Hurones, mi escrivano e contador de las armadas de la costa de la mar, les fagades que apreçien bien, e fiel e lealmente, las casas e solares de casas, de huertas e otros qualesquier suelos que fueren nesçesarios, e conplidero, de se comprar, para se fazer las dichas ataraçanas, e los almacenes, para en que estén las xarçias, e pertrechos e almacenar $/ 9$ otras cosas que a las dichas galeas e taraçanas pertenesçe que fueren más çercanos del dicho logar, así en la rua delant puente, conmo en los otros dichos logares. E otrosý, para en que se puedan fazer las casas en que more el tenedor de las dichas taraçanas. E las dichas casas, e solares e huertas, así por los dichos maestros carpenteros e albañeros, apresçiado, mando a vos, el dicho Juan de Sylva, o al que vuestro poder para ello oviere, que paguedes los tales presçios en que así fuere apresçiado, antel dicho mi contador e escrivano de las $/{ }^{12}$ dichas armadas, a las persona e personas cuyas fueren las tales dichas casas, e solares e huertas, resçibiendo d'ellos, e de cada uno d'ellos, los contrabtos e cartas de vençiones ${ }^{119}$ de las tales dichas casas, e solares e huertas que así conpraredes, e pagaredes e fueren apresçiadas, segund dicho es, con obligaçión, que fagan de lo fazer sano todo tienpo, segund que entendieredes que a mi servicio cunple. Otrosý, vos mando que fagades fazer un arco de puente nuevo, en la dicha rua de La Puente fasta la parte de la yglesia de los Cuerpos Santos de $/{ }^{15}$ la dicha villa, que es nesçesario e conplidero de fazer, por do se puedan botar las dichas galeas de las taraçanas a la mar, e de la mar se puedan poner dentro de las dichas taraçanas, cada que nesçesario e conplidero fuere. Otrosý, que fagades fazer un calze ${ }^{120}$ labrado de piedra e albañería, por do vaya el agua que viene de fuera de la dicha villa que agora entra por el dicho logar, do se an de fazer las dichas taraçanas; el qual calze, comiençe de fuera de la dicha villa, do fuere nesçesario, e tomé e reçiba en sy toda la /18 dicha agua que suele yr por el dicho logar, do se an de fazer las dichas taraçanas. E que vayan por de fuera de la çerca de la dicha taraçana, fasta el logar do entendieredes que sea nesçesario. E otrosý, que fagades çercar las dichas taraçanas de piedra, e cal e albañería, del altor e gordor de pared, asý en las costaneras, conmo en la çagera e delantera d'ella, segund que entendieredes que sea nesçesario e conplidero. Otrosý, vos mando que fagades fazer de nuevo, dentro de las dichas taraçanas, cinco galeas nuevas, e fagades adobar e ${ }^{21}$ reparar bien la galea real mía, que agora está en el logar de Maliaño, que es çerca de la dicha villa de Santander, fasta que ella, e las otras dichas cinco galeas que vos así mando que fagades, estén prestas para se botar al agua. Las quales dichas cosas, e cada una d'ellas, es my merçed e voluntad que vos, el dicho Juan de Sylva, fagades e mandedes fazer, o el que vuestro poder para ello oviere, e no otro alguno, non enbargante qualquier merçed que yo aya fecho, o fize, a otra qualquier persona, de lo que susodicho es, o de qualquier cosa d'ello que en esta carta se contiene, que $/ 24$ en contrario d'esta merçed que vos yo fago sea, o ser pueda. E revoco, e do por ninguna qualquier merçed que en contrario de lo contenido en esta mi carta, o parte d'ella, sea o ser pueda. E quiero, e es my merçed e voluntad, que non vala ni naya efeto alguno, de aquí adelante, la merçed que en contrario d'esto sea. E que las conpredes e paguedes de qualesquier maravedís que yo para ello mande librar al dicho Gonçalo Gonçáles de Setién, e mandare librar a vos, de aquí adelante, por antel dicho

119. Sic.

ISSN: 0210-7716 ISSN-e: 2253-8291

HID 46 (2019) 75-100

http://dx.doi.org/10.12795/hid.2019.i46.03 
Ferránd Sánchez de Hurones, mi contador e escrivano. E por esta mi carta, mando a $/ 27$ los mis contadores mayores de las mis cuentas, que todo lo que vos, el dicho Juan de Sylva, e otro por vuestro mandado, así gastaredes e pagaredes en todo lo que dicho es, por antel dicho Ferránd Sánchez, mi contador e mi escrivano, o ante su logarteniente, e mostraredes firmado de su nonbre, e signado de escrivano público, que vos lo reziban en cuenta. Otrosý, es my merçed que fechas e acabadas las dichas taraçanas, que vos, el dicho Juan de Sylva, seades mi alcayde e tenedor d'ellas, para en toda vuestra vida, ca yo, desde agora, por este mi alvalá, vos fago merçed $/^{30}[\ldots]$ toda vuestra vida. Otrosý, por este mi alvalá, mando a los mis contadores mayores que enbíen a vos, el dicho Juan de Sylva, todos los maravedís que yo he mandado, e mandaré librar, para fazer las dichas taraçanas, e para las dichas galeas, e para todas las otras cosas que a ellos pertenesçe, en qualquier manera. Otrosý, que vos den e libren mis cartas para el dicho Gonçalo Gonçáles de Setién, para que vos recudan con todas las quantías de maravedís que yo, fasta aquí, le mandé librar, en qualquier manera, ${ }^{33}$ así para fazer las dichas taraçanas, conmo para fazer las dichas galeas e para todas las otras cosas que a ellos pertenesçen. Al qual dicho Gonçalo Gonçáles, yo, por esta mi carta, mando que lo así faga, e cunpla luego, ca mi merçed e voluntad es quel dicho Juan de Sylva, o el que su poder oviere, faga fazer las dichas taraçanas, e galeas e todas las otras que para ello pertenesçen. E quel dicho Gonçalo Gonçáles, nin otro por él, non faga las dichas taraçanas e galeas, nin cosa alguna d'ello, non enbargantes qualesquier mis cartas e alvalás que en esta rasón le aya ${ }^{36}$ dado, las quales he, que por expresadas, bien así conmo sy de palabra a palabra, aquí fuesen puestas, por quanto es, entiendo, que cunple a mi serviçio. E los unos nin los otros non fagan ende al por alguna manera, so pena de la mi merçed e de diez mill maravedís para la mi cámara. Fecho seys días de dizienbre, año del nasçimiento del nuestro señor Ihesu Christo de mill e quatroçientos e veynte e siete años. Yo el rey.

Yo, el doctor Fernando Días de Toledo, oydor e relator del rey, e su ${ }^{39}$ secretario, lo fize escrivir por su mandado. Registrada.

1430, marzo, 15, ¿Sevilla?

Carta del almirante de Castilla Fadrique Enríquez a las autoridades municipales de Jerez de la Frontera, pidiéndoles que ayuden en todo lo posible a Juan de Caso, tenedor de los hornos del bizcocho.

AMJF, Acta Capitular de 1430, f. 20r (2 $2^{\text {a }}$ foliación).

Reg.: Orellana González 2015, p. 151.

Corregidor, e alguazil, e regidores, e jurados e omes buenos de la noble çibdad de Jerez de la Frontera, amigos, yo, don Fadrique, almirante mayor de Castilla, vos enb[ío] saludar, como aquellos por quien de buena voluntad faré lo que a honrras vuestras cunpla. Bien sabedes en como nuestro señor el rey, enbió mandar a Juan de Caso, te[nedor] de los sus fornos e almazenes del bizcocho, que fiziese en esa dicha çibdad [...] para la su flota, que su merçed manda armar. Porque vos digo, de parte de la dicha [carta del dicho señor] rey, e ruego de la mía, que cada, e quando el dicho Juan de Caso, o su lugar[teniente] oviere menester, para fazer el dicho vizcocho, molienda e carretas, para lleva[rlo al] Puerto de Santa María, a donde es acostunbrado, e otras cosas que sean no[to]rias al fazer el serviçio del rey, en el dicho ofiçio [d]el dicho Juan de Caso, que g[e lo] querades fazer dar, quel dicho Juan de Caso, o su lugarteniente, pagará lo acostunb[rado] que se suele pagar por cada cosa, lo qual, vos mucho agradesçere. E Dios vos te[nga] en su guarda. Escripta quinze días de 
março, año del nasçimiento del nuestro sal[va]dor Ihesu Christo de myll e quatroçientos e treynta años. El almirante.

1430, mayo, 2, Burgos.

Carta de Juan II a las autoridades municipales sevillanas, ordenando realizar un repartimiento de 150 galeotes entre Sevilla y las demás poblaciones de su arzobispado, para la armada real que se estaba armando contra los reyes de Aragón y Navarra.

AMS, Papeles del Mayordomazgo, 1429, $\mathrm{n}^{\circ} 130$.

Reg.: Collantes de Terán y Delorme 1980, p. 259.

Don $^{121}$ Juan por la graçia de Dios rey de Castylla, de León, de Toledo, de Gallizia, de Sevilla, de Córdova, de Murçia, de Jahén, del Algarve, de Algezira e señor de Vizcaya e de Molina, a los alcalldes, e alguazil, e XXIIIIos, e jurados de la muy noble çibdat de Sevilla, salud e graçia. Bien sabedes conmo yo he mandado armar en esa çibdat veynte galeas e çiertas carracas, para en ¿prestençias? de la guerra que yo he con los reyes de Aragón e Navarra, de más de las otras galeas, e naos e otras fustas que, asý mesmo, mando armar en Santander. Para lo qual, fazer yo mandé repartyr, e fueron repartidos por las villas e lugares de las behetrías de los mis regnos, cierto número de galeotes. E non envargante el dicho repartimiento, mandé poner tabla en esa dicha çibdat, para que los que quisiesen tomar dineros por galeotes, e yr en la dicha armada, que fuese luego dado mill maravedís a cada uno. E agora el almirante, mi primo, e el mi armador, me enviaron fazer relación, que non envargante, que en aver e tomar los dichos galeotes se ha puesto çiertas diligençias que no se han podido, nin pueden, aver tantos galeotes conmo son nesçesarios. E que por esta razón, las dichas galeas están detenydas de se armar, e de partyr, para yr en mi serviçio. E yo, viendo el grand deserviçio que me ha venido, e viene, e aún podría venir por el dicho detenimiento, fue, e es mi merçed, de mandar repartyr en esa dicha çibdat, e en las villas e lugares de su arçobispado, e en la çibdat de Córdova, e en las villas e lugares de su obispado, cierto número de galeotes, entre los quales, copó a esa dicha çibdat se Sevilla, e villas e lugares de su terra, çiento e çynquenta galeotes. Porque vos mando que luego, vista esta my carta, syn otra luenga, nin contradiçión nin escusa alguna, repartades en esa dicha çibdat, e en las villas e lugares de su terra, los dichos çiento e çinquenta galeotes; e los presentedes en la my tabla al mi armador, por ante el mi escrivano de la armada. E los castigades, e apremiedes, que resçyban lu[e]go los dichos mill maravedís, a cada galeote, en la dicha tabla. $\mathrm{E}$ que entren lu[e]go en las dichas galeas, porque, syn detenimiento alguno, sean armadas e fagan su viaje. E cunple que en esto pongades la mayor diligençia que ser pueda, porque lu[e]go haya efeto ${ }^{122}$, que en ello, nin en parte d'ello, non tengades, nin consyntades tener, mañas de escusas nin de delaçión, ca yo, por esta mi carta, mando a los lugares e personas que por vos fueren requeridos, que lu[e]go, cumplan con efecto el repartimiento que fizieredes. E los unos nin los otros non fagades, nin fagan, ende al, so pena de la mi merçed, e de privaçión de los ofiçios e de confiscaçión de todos vuestros bienes para la mi cámara. Dada en la çibdat de Burgos, dos días de mayo, año de MCCCCXXX años. Yo el rey.

Yo, Diego Romero, la fiz escrivir por mandado de nuestro señor el rey.

121. Al margen izquierdo: los CL galeotes quel rey mandó dar a Sevilla e a su terra, para el armada de las galeras.

122. Sic. 
1430, agosto, 31, Elche.

Carta del consell de Elche al de Barcelona, relatando el ataque de las tropas de la flota castellana a dicha población.

AME, a7, ff. 124v-126v.

Als molt honorables e molt savis senyors nostres, los senyors consellers de la noble ciutat de Barcelona.

Molt honorables e molt savis senyors nostres, vostra honorable senyoria, cer //125r tificam que en lo disapte ques contaven vint e sis dies del present mes d'agost, estant lo estol e naus de aquell, del rey de Castella, surtes al Cap del Aljup, terme d'aquesta vostra vila d'Elig, qui per totes eren XXXII naus; en lo dit dia, vengren d'aquelles a la dita vila dos milia cinchcents homens, ¿axi de? castellans, venint ab aquells en Johan de Tovar, capita del dit estol. Los quals, batalles arreglades, e penons esteses, plegaren als ravals e moreria de aquesta dita vila, e entraren dins. [E] aquells, esvahits les barreres, e robaren e cremaren algunes cases dels dits ravals. E veent aço, nosaltres, e los vehins d'aquesta vila, jaquint, dins aquella çerta gent, per custodia d'aquella, jatsia hi fos poca gent per causa de les morts qui hi son, is que certa gent e vehins de la dita vila, [foren] a resistir e ofendre als dits castellans. E valerosament, e ab gran esforç, en defen $/ / 125 \mathrm{v}$ sio de la dita vila, e en exalçament de la corona reyal, los de la dita vila feren retraure e exir dels dits ravals e moreria los dits castellans, fahent brega ab aquells, en tal manera, quen mataren, e han mort en los dits ravals, e apresonats, alguns d'aquelles. De que los dits castellans, erent retraguts, [e] se partiren de la dita vila, e sen tornarem a les dites naus. E los dits vehins de aquesta dita vila seguiren aquells, tro en lo Pinatar, qui es prop de la torre del dit cap, tro en lo qual dit loch de Pinatar, los dits vehins d'Elig, avant detras, encalç dels dits castellans, ne han mort e apresonats asats de aquelles. Dels quals dits castellans, los dits vehins de la dita vila d'Elig han presa e hauda certa desferra, ço es, armes, cuyraçes, balestes, paveses, glavis e altres armes, les quals, son en la dita vostra vila. //126r En lo qual dit loch del dit Pinatar, avant detras, en lo encalç dels dits castellans, los vehins de la dita vila de Elig erent avisat per nosaltres, sobrevench lo molt noble don Pero Maça de Liçana, governador d'aquesta partida, el qual, ab certa gent de cavall e de peu que ab si amenava de la vila d'Alacant e de altres parts, venia al devant als dits castellans. El qual dit noble, erent-se avançat pus de miga legua, ab set homens a cavall, ab si, de la altra sua gent que ab si amenava en lo dit loch del dit Pinatar, feri, valerosament, en la davantera dels dits castellans. E mataren e apresonant lo dit noble, ensemps ab los dites vehins d'Elig, los quals sens cansar, avant en lo dit encalç, feren anar en fuhyta les dits castellans //126v tro en la hora de la mar, a davant les dites naus, e feren encerrar e metre aquells en la torre del dit cap e cortigo d'aquells. E en apres, veent los dits castellans sobrevenir la dita gent del dit noble, e altra gent de la dita vila d'Elig, qui seguien lo dit encalç, aquells dits castellans, a gran cuyta e temor, se recolliren els, covench recollir en les dites naus. E en apres, en lo dilluns apres seguent, aquells partiren e sen anaren del dit port. E per tal, molt honorables e molt savis senyors nostres, com creem que de les dites coses haurets, ne consultam e certificam vostra honorable senyoria. E mantangaus nostre senyor Deu per molts anys, e bons, al seu sant servey. Escrita en la vostra vila d'Elig, a XXXI dies del mes d'agost del any mil CCCCXXX.

A vostre servey e manament prestes, los procurador, batle, justicia, jurats e consell de la vostra vila d'Elig. 
1430, septiembre, 4, Madrigal.

Albalá de Juan II al almirante Fadrique Enríquez, ordenándole que jurase y firmase las treguas acordadas en Majano entre los reyes de Castilla, Aragón y Navarra.

AGS, Patronato Real, leg. 12, doc. 39, f. 307v.

Yo el rey enbío mucho saludar a vos don Fadrique, mi primo, e mi almirante mayor de Castiella e del mi consejo, como aquell que amo, e preçio e de quien mucho fio. Fagovos saber que yo, por otra mi carta, vos enbié notificar en como yo di tregua a los reyes d'Aragón e de Navarra, e a sus reynos, por çinco años. La qual, fue firmada e jurada por mí e por los dichos reyes, e por los perlados, e nobles e caballeros de los reynos, de cada una de las partes que por ello fueron nombrados. E vos enbié mandar que jurassedes la dicha tregua, e las seguridades e las otras cosas contenidas en los capítoles ${ }^{123} \mathrm{~d}^{\prime}$ ellas. E pareçe que fasta aquí non lo havedes fecho, porque los misatgeros non puediron ${ }^{124}$ haver vuestra persona, por vos ser ocupado en mi serviçio en la mar. Por ende, yo vos mando enbiar agora, con el portador de la presente, los dichos capítoles; e asín mismo, la forma de cómo los havedes de jurar, todo senyalado del mi relator. Porque vos ruego e mando, si serviçio e plazer me havedes de fazer, que luego firmedes e juredes los dichos capítoles, segunt e por la forma que vos serán mostrados por el dicho portador, porque sean traýdos luego ante mí, signados en manera que fagan fee, e vengan dos instrumentos d'ello, en un tenor, porque dentro, en cierto término, se han de enbiar el uno al rey [de] Aragón e otro al rey de Navarra. Cosa alguna non fagades ende al. Dada en la vila de Madrigal, quatro días de setiembre, anno de trienta $^{125}$. Yo el rey.

Yo, el doctor Ferrando Díaç de Tholedo, hoydor e referendario del rey, e su secretario, la fize escribir por su mandado.

\section{BIBLIOGRAFÍA}

Abellán Pérez, Juan (1984), Colección de documentos para la historia del Reino de Murcia, vol. XVI, Murcia-Cádiz, Academia Alfonso X el Sabio/Universidad de Cádiz.

Almúnia, Antoni (2008), Libre de tots los actes, letres, privilegis y altres qualsevol provisions del consell d'Oriola, València, Universitat de València.

Álvarez Palenzuela, Vicente Ángel (2017), "El precio de la guerra: algunos datos sobre el enfrentamiento entre Castilla y Aragón y Navarra. 1429-1430", Estudios sobre Patrimonio, Cultura y Ciencias Medievales, 19, pp. 61-92.

Aznar Vallejo, Eduardo (2006), "La organización de la flota real de Castilla en el siglo XV”, en González Jiménez, Manuel (coord.), La Península Ibérica entre el Mediterráneo y el Atlántico: siglos XIII-XV, Cádiz, Sociedad Española de Estudios Medievales, pp. 323-339.

123. Sic.

124. Sic.

125. Sic. 
Aznar Vallejo, Eduardo (2009), "La guerra naval en Castilla durante la Baja Edad Media", En la España Medieval, 32, pp. 167-192.

Bello León, Juan Manuel; Martín Perera, Alejandro (2012), Las atarazanas de Sevilla a finales de la Edad Media, Murcia, Sociedad Española de Estudios Medievales.

Bellot, Pedro (2001), Anales de Orihuela, vol. I, Murcia, Real Academia Alfonso $\mathrm{X}$ el Sabio/Instituto Alicantino de Cultura Juan Gil-Albert.

Bonnín Femenías, Marc (2011), "Una pesada herencia, los castillos reales en la Mallorca del siglo XV", Anales de la Universidad de Alicante. Historia Medieval, 17, pp. 411-423.

Calderón Ortega, José Manuel (2003), El almirantazgo de Castilla: historia de una institución conflictiva, Alcalá de Henares, Universidad de Alcalá de Henares.

Calderón Ortega, José Manuel (2006), "La intervención de marinos cántabros y vascos en la campaña naval de 1430 y los intentos por extender la jurisdicción del Almirantazgo de Castilla a los puertos del norte peninsular", Itsas Memoria. Revista de Estudios Marítimos del País Vasco, 5, pp. 53-67.

Cañas Gálvez, Francisco de Paula (2007), El itinerario de la Corte de Juan II de Castilla (1418-1454), Madrid, Sílex.

Cañas Gálvez, Francisco de Paula (2012), Burocracia y cancillería en la corte de Juan II de Castilla (1406-1454). Estudio institucional y prosopográfico, Salamanca, Universidad de Salamanca.

Casado Soto, José Luis (1983-1986), "Reconstrucción de las reales atarazanas de galeras de Santander", Anuario del Instituto de Estudios Marítimos Juan de la Cosa, V, pp. 59-84.

Casado Soto, José Luis (1985), "Santander, el caso de una villa de desarrollo urbano bajomedieval paralizado en el siglo XVI", En la España Medieval, 6, pp. 641-670.

Collantes de Terán y Delorme, Francisco (1980), Inventario de los papeles del Mayordomazgo del siglo XV, vol. II, Sevilla, Ayuntamiento de Sevilla.

Díaz Borrás, Andrés (2002), El ocaso cuatrocentista de Valencia en el tumultuoso Mediterráneo, 1400-1480, Barcelona, Consejo Superior de Investigaciones Científicas.

Estepa Díez, Carlos (2006), "Fiscalidad de origen militar y concejos de realengo en la Castilla del Becerro de las Behetrías. Dos ejemplos: los pagos al castillo de Burgos y la fonsadera naval”, en Menjot, Denis; Sánchez Martínez, Manuel (coords.), Fiscalidad de estado y fiscalidad municipal en los reinos hispánicos medievales, Madrid, Casa de Velázquez, pp. 3-20.

Fernández de Navarrete, Martín (1858), Colección de los viajes y descubrimientos que hicieron por mar los españoles desde fines del siglo $X V$, vol. I, Madrid, Imprenta Nacional.

Fernández Duro, Cesáreo (2010), La marina de Castilla (facsímil de la edición original de 1894), Valladolid, Maxtor. 
Fernández Rojas, Matilde (2013), Las reales atarazanas de Sevilla, Sevilla, Diputación de Sevilla.

Flores Díaz, Manuel (2018), Leones y castillos en la mar. Castilla y el dominio del mar en la Edad Media (1248-1476), Madrid, Ministerio de Defensa.

Gago-Jover, Francisco (2002), Vocabulario militar castellano (siglos XIII-XV), Granada, Universidad de Granada.

García de Castro, Francisco Javier (2014), La marina de guerra de Castilla en la Edad Media (1248-1474), Valladolid, Universidad de Valladolid.

García de Santa María, Álvar (1892), Crónica de don Juan II de Castilla (Colección de documentos inéditos para la historia de España, vol. C), Madrid, Imprenta de Rafael Marco y Viñas.

García Isaac, José Marcos; Idáñez Vicente, Carmen (2018), “Una investigación naval en Santander a finales del siglo XIV: la pesquisa de Juan Rodríguez de Salamanca contra Gonzalo Pérez de Herrera", Cuadernos Medievales, 24, pp. 78-99.

Hinojosa Montalvo, José (1989), "El cap del Aljup, puerto medieval de Elche”, Mayurqa, 22/1, pp. 311-324.

Orellana González, Cristóbal (2015), "Registro cronológico de acuerdos capitulares de Jerez de la Frontera, 1409-1430”, Revista de Historia de Jerez, 18, pp. 83-156.

Pérez-Mallaína, Pablo E. (2014-2015), "Los responsables de las atarazanas de Sevilla durante la Baja Edad Media", Norba. Revista de Historia, 27-28, pp. 201-226.

Ponsoda López de Atalaya, Santiago (2010), “Una guerra en la frontera: el enfrentamiento entre Aragón y Castilla en las tierras de la Gobernación de Orihuela (1429-1430)", en Francisco Toro y José Rodríguez (coords.), VII Estudios de Frontera: islam y cristiandad (siglos XI-XVI), Jaén, Diputación de Jaén, pp. 697-710.

Riquer, Martí de (2004), Vida i aventures del cavaller valencià don Pero Maça, Barcelona, Quaderns Crema.

Rosell, Cayetano (ed.) (1953), Crónicas de los reyes de Castilla, vol. III, Madrid, Biblioteca de Autores Españoles.

Ryder, Alan (1992), Alfonso el Magnánimo. Rey de Aragón, Nápoles y Sicilia (1396-1458), Valencia, Edicions Alfons el Magnànim.

Sáiz Serrano, Jorge (2008), Caballeros del rey. Nobleza y guerra en el reinado de Alfonso el Magnánimo, València, Universitat de València.

Salazar y Castro, Luis de (1685), Historia genealógica de la casa de Silva, vol. I, Madrid, Melchor Álvarez y Mateo de Llanos.

Sánchez Saus, Rafael (1987), "Las milicias concejiles y su actuación exterior: Sevilla y la guerra de Granada (1430-1439), En la España Medieval, 10, pp. 393-415.

Solórzano Telechea, Jesús Ángel (1995), Colección diplomática del Archivo Municipal de Santander (1295-1504), Santander, Fundación Marcelino Botín. 
Solórzano Telechea, Jesús Ángel (2002), Santander en la Edad Media: patrimonio, parentesco y poder, Santander, Universidad de Cantabria/Ayuntamiento de Torrelavega.

Unali, Anna (2007), Marineros, piratas y corsarios catalanes en la Baja Edad Media, Sevilla, Renacimiento.

VV.AA. (1866), Cortes de los antiguos reinos de León y de Castilla, vol. III, Madrid, Real Academia de la Historia.

Zurita, Jerónimo (2007), Anales de la Corona de Aragón, vol. V, Zaragoza, Institución Fernando el Católico. 